\title{
English translation of $A$ Poem Composed by the Poet upon his Translation of the Tale of Melibea and Calisto, Joseph ben Samuel Tsarfati, 1507
}

\author{
Amy Baron \\ University of Oxford
}

\begin{abstract}
The original manuscript of Tsarfati's poem can be found in the Bodleian Library (Oxford), MS Mich. 353, fol. 142a-142b. It is listed in the Neubauer Catalogue (1886: 554, n²). For my translation, I have followed the edition by Cassuto (1935: 125-128). I have taken note of Cassuto's amendments to the original text, and I have occasionally suggested a return to the expression of the text on the original manuscript. Punctuation has been added to render the text understandable, but is no way defin tive. Where necessary, I will mention the alternative interpretations by McPheeters (1985) and Carpenter (1993, 1997). Hereafter, I will refer to these works only with the author's name. For the biblical quotations, I resort to the Jewish Publication Society version of the Old Testament (1917), and to Russell's edition of the Tragicomedia (Rojas 1991) for the quotations of Celestina.
\end{abstract}


1 Turn and look ${ }^{1}$, friends ${ }^{2}$, to the war of lovers ${ }^{3}$, I they who have been captured in the snare ${ }^{4}$ of desire ${ }^{5}$,

2 As they convince each other with their retorts, I with witty words and entertaining proverbs ${ }^{6}$.

3 And the maidens' fierce rages and fears ${ }^{7}$ : I their strife and their love are intertwined ${ }^{8}$.

\section{Sweet words which flow from the lips of lovers, I as they speak with delightful ${ }^{9}$ discourse to beautiful maidens,}

1.- «Tornad» (McPheeters), "Hark» (Carpenter). But ונפ can also have the sense of "turn and look», especially when followed by לא. The sense of gaze is essential for Rojas too, who encourages his readers to look at the love story of Calisto and Melibea: «notad bien la vida que aquestos hizieron» (p. 210), «Pues aquí vemos cuán mal fenescieron / aquestos amantes» (p. 621).

2.- Cassuto here recalls Song 6:1: (where has) your beloved one turned himself». In many cases, דוז means «beloved, love» but can also carry the meaning of "friend». McPheeters and Carpenter opt for «amigos» and «friends» respectively, surely influenced by Rojas's El autor a un su amigo.

3.- The concept of war echoes the main idea of Rojas's original prologue to the Tragicomedia: "Todas las cosas ser criadas a manera de contienda o batalla» (p. 213).

4.- The original wording ח ח literally means «bird-trap», but is often used in a metaphorical sense, denoting a source of calamity. Together with [ידוכל [«the captured ones»; «they who have been captured»], Cassuto identifies this word pair in Isa 24:18 ("he shall be taken in the trap»), and Jer 48:44 ("he shall be taken in the trap»). Both allusions present the powerful imagery of an inescapable trap. The word $\operatorname{s}$ also recalls Prov 7:23, which describes the urgency with which the foolish man chases after the seductive, enticing woman. He is like "a bird who hastens to the snare». This verse warns that the man's speedy surrender to the woman's seduction in this manner has grave consequences, for «it is at the cost of his life». The reference to Prov 7:23 is certainly identifiable, although it has been slightly manipulated by Tsarfati to fit the specific situation of Melibea and Calisto, and to adapt this warning to females too. However, the message of Prov 7:23, which warns specifically against women, is appropriate for the general tone of Tsarfati's poem from verse 10 onwards, which largely urges men to be aware of the dangers and the wiles of women.

5.- Despite being a topical concept, this reference to capture could echo Rojas's El autor a un su amigo: "cuya juventud de amor ser presa se me representa aver visto» (p. 200; emphasis is mine).

6.- The wording of the second hemistich echoes more or less closely Rojas's «otros pican los donayres y refranes comunes» (p. 218).

7.- Here, the construct form of זע, which applies to both the «rages» and the «dreads» operates as an adjective. McPheeters follows the Hebrew structure, maintaining the nominal sense: "la fuerza de la fiebre y el miedo». Note that «the maidens' fierce rages» resembles «la ira de Melibea» in act I, as well as her contradictory behaviour in acts IV and X.

8.- Literally מידמצ has the sense of a couple or a pair together. From the segholate noun meaning "couple», "pair». Note that this idea of love, as intertwined with the struggle against it, is present in Melibea's opening monologue in act X.

9.- Cassuto refers to Prov 8:6: «for I will speak excellent things». Whilst McPheeters translates as "príncipes» and proposes that the line should read «cuando hablan con las bellas hijas de príncipes». This is plausible in consideration of Melibea's noble lineage. However, I am inclined to translate the word in the adjectival sense for several reasons: from a grammatical point of view, in order to maintain a parallel between «sweet words» and "delightful discourse», and according the evidence from Proverbs. However, scholarly debate regarding the meaning of רבדא םידיגנ יכ in Prov 8:6 has also considered a revocalisation of the word טידגי טידיגנ, meaning «straightforward». This revocalisation provides an adequate parallel 
5 Are their weapons as they wrestle with their desire ${ }^{10}$. I And the deceptions and counsels of servants ${ }^{11}$,

6 Whose wiles are weapons of destruction ${ }^{12} \mid$ to place fracture and ruin in the heart of a man.

7 And their conspiracy to steal their master's glory ${ }^{13}, \mid$ as they rebel against him at all times.

8 And there, the craftiness and deceptions of old crones $^{14}$, I who lay their traps everywhere ${ }^{15}$.

9 And there, maid-servants ${ }^{16}$ will have conversations I to light a fir ${ }^{17}$ and firebrands in the heart of lovers

10 And mistresses sate ${ }^{18}$ themselves with gall and wormwood ${ }^{19}$ : I their multitude and proximity arouse suspicion.

to in the same biblical verse, which is also an adjective qualifying the straightforward nature of the words. However, I consider the interpretation of the word as «delightful» to be more poetically fitting.

10.- Verses 3-5 correspond to the beginning of act I of Celestina, where Calisto approaches Melibea with with his amorous discourse, to which she reacts negatively.

11.- This verse, together with verse 8, seems to follow the original sequitur: «los engaños de las alcahuetas y malos y lisonjeros sirvientes» (p. 221).

12.- Here, מהילכ seems superfluous. Cassuto and Carpenter make reference to Gen 49:5: "Simeon and Levi are brethren; weapons of violence their kinship». This allusion to the rape of Dinah and the subsequent murder of Shechem, Hamor and other men, exemplifies the potential dangers and destruction of sexual relations resulting from desire. Verse 6 appears to relate to the second part of verse 5 , that is, to the disloyal servants. In this way, as my translation aims to express, a distinction is made between the servants' "weapons of destruction", i.e. their disloyalty; and the lovers' instruments in "the war of love», i.e. their words.

13.- Cassuto here refers to Lucretia, who helps Calisto to come at night to visit Melibea. This is an insult to her master's honour (Pleberio's). I disagree with Cassuto and consider verse 7 to be a continuation of verses 5 and 6 , and therefore, to refer to Calisto's male servants, whose behaviour threatens Calisto's honour.

14.- See note 12.

15.- Cassuto explains that at the end of verse 8 , the original manuscript actually repeats the final two words of the previous line, which are also preceded by לכב, in an example of error by homeoteleuton. According to Cassuto, this mistake has been corrected by the scribe on the original manuscript.

16.- This should be a reference to Lucrecia, but I have not been able to identify the scene to which Tsarfati could be referring here. It is very likely that the author has already begun to dissociate from his model and started a more general review of situations related to love and lovers.

17.- Cassuto notes that the original manuscript reads ["man»], but has amended it to ["fire»], according to the semantic field of the verse.

18.- Written as הנורת in the original manuscript, but Cassuto amends this to הניורת, and follows the use of the verb in Lam 3:15: «he has sated me with wormwood». הנורת comes from the Hebrew root "to sing", which would be less fitting here. As such Cassuto's correction seems justified.

19.- This recalls the woman's connection to wormwood in Prov 5:4: «her end is bitter as wormwood». This is a text replete with imagery regarding the wiles of women. 
11 And the voice of lovers in sorrowful sufferings, I their bodies torn apart ${ }^{20}$ by anguish,

12 Their crying of their lamentation, the wailing of their desperation. I Full of wretched anger, they wander amongst the scorned ${ }^{21}$

13 And they shout and they moan ${ }^{22}$, I and in every moment, every misfortune, they tremble ${ }^{23}$.

14 And in their anguish is pain, speech and mourning too, I as they speak. They are like helpless wanderers ${ }^{24}$.

15 And there ${ }^{25}$, all the wise men like $\mathrm{Calcol}^{26}$, I are despoiled at the hand of a shameless woman ${ }^{27}$,

16 And they are defeated barefoot ${ }^{28}$ by the thousands, I and scattered across every corner they roam.

17 I will make known ${ }^{29}$ their discourse, their wandering and their struggle, I as they suffer the load of a thousand mules.

18 And the time will come when they will be weary, grown old, and exhausted I from these burdens which are too heavy for them ${ }^{30}$,

20.- This could also be translated as «separated», thereby referring to the tragic impossibility of two lovers being united (as is eventually the case with Calisto and Melibea). On the other hand, bodies "separated by anguish" in the sense of "torn apart by anguish" is an example of Tsarfati employing the Ovidian trope of love as a physical force, which destroys the concrete body, as well as the soul.

21.- Cassuto recalls Job 7:4: «I am full of movements to and fro».

22.- Literally: «their shouts and their moans». I have translated these nouns in a verbal sense.

23.- Cassuto points to a similarity with Ez 26:16 and 32:10: «and they shall tremble at every moment».

24.- As Cassuto points out, the word מידורמ ["they who are cast out»], to denote helpless destitution in Isaiah 58:7 ("Is it not to deal thy bread to the hungry, and that thou bring the poor that are cast out to thy house? when thou seest the naked, that thou cover him, and that thou hide not thyself from thine own flesh?»).

25.- Literally: «dwelling place».

26.- This may be a direct reference to 1 Kings 5:11, in which «all the wise men like Calcol» are enumerated.

27.- In Judg 5:27 («At her feet he sunk, he fell, he lay; at her feet he sunk, he fell; where he sunk, there he fell down dead»), the word דודש, which is placed in Tsarfati's poem at the end of verse 15, is used to describe Sisera's death, confirming Cassuto's suggestion that the second half of verse 15 is an allusion to Judg 4-5, which relates the downfall and destruction of Sisera at the hands of Deborah and Jael.

28.- Cassuto points out that the original manuscript [יפחו ["free», «innocent»]. He has amended this to [יפחי ["barefoot»]. This emendation is more logical and fitting with respect to the destitute, downfallen and wandering victim of love.

29.- McPheeters translates «Fraternal» [N] from the root $\pi$ [«brother»]. I agree with Carpenter, who translates it as "I shall tell», from the root הוח. This is the first-person form of a ל ה

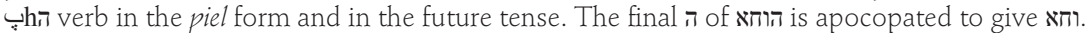

30.- Similarly to Prov 5:8-11 («Remove yourself far away from her [...] lest you give your vigour unto others, and your years unto the cruel / [...]/ and you moan, when your ends 
19 And there isn't understanding, and there isn't correct counsel ${ }^{31}, \mid$ and there isn't a guide, and there isn't someone to direct the path ${ }^{32}$.

20 Maidens conquered the man, I and, in fury, placed his feet in stocks ${ }^{33}$.

21 And on what will lovers' gazes lean? I And were will they find a base for support?

22 In love there is no shelter or cover I and no-one who shows pity or performs acts of kindness ${ }^{34}$.

23 And she ${ }^{35}$ will break and bury the body of a man, I and she will heap fear in the heart of a warrior,

24 And she will humiliate and thwart haughtiness of spirit, I and she will crush the glory of a military leader ${ }^{36}$.

25 When in anger, she expels the name and the wisdom of men I from their place in the Supreme Court.

26 From youth until old age and white hair ${ }^{37}$, I beneath her yoke ${ }^{38}$, officials will serve her.

27 At all times those fools, deceived I arrange and fabricate praises on her behalf ${ }^{39}$.

28 I shall compare their deeds ${ }^{40}$ to an absence of rain I though the heavens be full of winds and clouds.

comes, when your flesh and body are consumed»), Tsarfati explains the soul-destroying nature of the pursuit of women.

31.- Prov 5:23: «He shall die for lack of instruction».

32.- Prov 5:13: «Neither have I hearkened to the voice of my teachers, nor inclined my ear to those who instructed me».

33.- Job 13:27 («You put my feet also in the stocks»); 33:11 («He puts my feet in stocks»).

34.- Translation borrowed from Carpenter.

35.- The word איה is ambiguous here. It is most likely referring to the nearest preceding feminine noun, that is, «love» הבהאיה]. However, it may also be applied to a woman, maybe one of the aforementioned maidens in verse 20. In either case, the poet makes clear that both woman, and the personification of love itself, are prone to the destruction of man.

36.- Another potential reference to Sisera (see note 28).

37.- According to Cassuto, old age is expressed in this way in Isa 46:4 («Even to old age I am the same, and even to hoar hairs will I carry you») and Ps 71:18 ("And even unto old age and hoary hairs").

38.- Cassuto's vocalisaton of הלעב without the mappiq in the final ה does not imply possession the part of the female subject. However, I agree with Carpenter's translation of the word as «yoke» with the female singular possessive suffix. The image of men surrendering their liberties to the female, as slaves to her oppression, is appropriate here. An alternative reading of the verse with הלעב as "Woman» or "mistress» or "necromancer» rather than "yoke» would also make sense, but does not provide as powerful or as fitting an image.

39.- Verses 21-27 develop ideas quite similar to those expressed in Pleberio's lament in act xXI, when he complains about love.

40.- I have not followed Cassuto's amendation: הלעפ ["her deeds]. Instead I have employed the form of the suffixed noun on the original manuscript: [לעפ ["their deeds»], which Carpenter follows too. McPheeters' translation is ambiguous: "sus obras» may refer either to many deeds of the aforementioned «fools» (v. 27), or of the many deeds of «her» (love, or 
29 And it is in vain that songs entice women, I and it is pointless to moan like mothers over their only sons ${ }^{41}$.

30 But silver will gather the hearts of women ${ }^{42}$, I and giving others scarfs with shrouds.

31 And gold will raise the haughtiness of a lover. I From every bramble will sprout a spikenard ${ }^{43}$.

32 And he ${ }^{44}$ is a prince, who elevates men, I and brings joy to the old and the young.

33 Many gifts will capture the heart of gazelles ${ }^{45}, I$ and a necklace upon the throat will lead away great anger ${ }^{46}$.

presumably, woman). If the didactic value of Tsarfati's poem is to be emphasised, the deeds of either the [יליוא [ffools»] or of "love»/»woman», make sense in the present context. How-

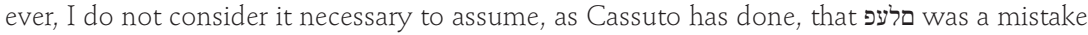
on the part of the scribe. In explaining the injudicious actions of the [יליוא ["fools»] in verse 27 , it is perfectly logical that the poet should make a judgement upon these actions in the subsequent verse.

41.- Cassuto identifies here an allusion to Jer 6:26 («make thee mourning, as for an only son, most bitter lamentation») and Zech 12:10 ("and they shall mourn [...] as one mourns for his only son").

42.- A possible allusion to Delilah in Judg 16:5 ("And the lords [...] said unto her: 'Entice him $[\ldots]$ and every one of us will give you eleven hundred pieces of silver'»). The mention of also recalls Prov 8:10, in which the voice of Wisdom encourages her listeners to choose instruction over money ("Receive my instruction, and not silver, and knowledge rather than choice gold»). Tsarfati is probably presenting a subtle indication to choose wisdom and prudence over superficial luxuries such as wealth and woman's beauty.

43.- Plant imagery is also found in Song 1:12 ("my spikenard sent forth its fragrance») and 4:13-14 ("Your shoots are a park of pomegranates, with precious fruits; henna with spikenard plants»).

\section{4.- Referring to ["gold»].}

45.- I am inclined to translate this as «the heart of gazelles» although both Carpenter and McPheeters translate תואבצ בל as "strong heart» and "fuerte corazón", respectively, perhaps

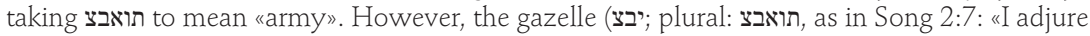
you, $\mathrm{O}$ daughters of Jerusalem, by the gazelles, and by the hinds of the field, that ye awaken not, nor stir up love, until it please») was a common image associated with women in $\mathrm{He}$ brew love poetry, and I consider it more fitting here.

בוט 46.- Cassuto amends the original manuscript, writing זורח בר ["great anger»] in place of וורח ["good anger»]. Therefore, according to Cassuto's edition of the poem, I have translated this line as "And a necklace upon the throat will lead away great anger». Carpenter also follows Cassuto's edition of the poem, and translates the line as "necklaces will calm fierce ire». This bears great resemblance to McPheeters's translation «con collares se aplacara grande ira». However, I find reason to suggest an alternative to Cassuto's amendment here. From the verb ונר, the cognate noun ור ור (ringing) cry». This has positive connotations in several instances. For example, in Isa 65:14, it is also connected with the word ["good»]: «Behold my servant shall sing with a joy of heart». The word also has positive implications in Ps 32:7 ("songs of deliverance»), and Ps 145:7 ("they shall sing of your righteousness»). I therefore propose that the original riרח should not be abandoned in translation. Literally meaning «happiness from a cry», it can be more poetically rendered as "(hear / behold) a delighted cry when a necklace is placed upon her neck». Whilst both interpretations refer to the joy that the gift of a necklace brings to a woman —and perhaps more specifically to Celestina's 
34 Give gifts and presents to the maidens I and, to the attractive ones, continuous changes of raiment ${ }^{47}$ !

35 Indeed, her anger will relax ${ }^{48}$ when a ring is placed on her nose, I and bracelets on her hands ${ }^{49}$.

36 And thus the maiden will desire her lover, and kiss him, I and she will satisfy his desires with precious things.

37 No longer insolent ${ }^{50}$ in her behavior, I she will boil food according to his desire, in order to satisfy him.

38 How good and how pleasant ${ }^{51}$ it is, modest ones, I to turn from her! Behold everyone who shuns her ${ }^{52}$ !

39 Both, Solomon and David, are witnesses I to the wiles and fetters of women ${ }^{53}$.

excitement upon receiving a gold chain as a token of gratitude from Calisto-, I do consider my proposed translation to be more fitting in the context, and more appropriate according to the grammar. As a result, an atranslation would be: "Hear a delighted cry I when a necklace is placed upon her neck».

47.- «for comely women fine attire» (Carpenter), «a las mujeres hermosas ropajes y vestidos» (McPheeters). My translation comes from the biblical rendering of the phrase "changes of raiment» as found in Judg 14:12 ("I will give you thirty linen garments and thirty changes of raiment»), and 2 Kings 5:22 ("Behold, even now there are come to me from the hill-country of Ephraim two young men of the sons of the prophets; give them, I pray thee, a talent of silver, and two changes of raiment»). Seen in Cassuto.

48.- Cassamends ברי on the original manuscript to פמר (from, "to sink, relax»). The allaying of anger through the bestowment of gifts is more convincing in this context than the exacerbation of anger by the bestowment of gifts.

49.- As both Cassuto and Carpenter point out, this is an allusion to Gen 24:27 («and I put a ring upon her nose and bracelets upon her hands»), and to Ez 16:11-12 ("I put bracelets upon your hands and a ring upon your nose»).

50.- Cassuto distinguishes between the two uses of דיזת. The first refers to acting rebelliously, as in Ex 21:14 («and if a man should act presumptuously to his neighbour»), and corresponds to the first hemistich of the verse. The second is an allusion to Gen 25:29 ("And Jacob sod pottage; and Esau came in from the field, and he was faint»), when Jacob boils pottage for Esau to satiate his hunger, and fits with the content of the second hemistich.

51.- Ps 133:1: «Behold, how good and how pleasant it is for brethren to dwell together in unity!».

52.- Cassuto amends the original manuscript from מידדצ לא רוס to. The amended version might translate literally as "turn to the sides», which doesn't seem meaningful or appropriate here. I have arrived at my translation by maintaining what is written on the original manuscript. I have taken מידזצ as the present plural participle of the verb דלצ from the Arabic meaning "to shun, alienate, turn away", and I have carried over the sense of the female object from the earlier part of the line, "to turn from her» [הנמ].

53.- David and Solomon are presented as examples of victims of women in Celestina as well: «Di, pues, esse Adam, esse Salomón, esse David, esse Aristóteles, esse Vergilio, essos que dizes, ¿`cómo se sometieron a ellas?» (p. 242). 
40 Within these women reside angels of death, I together with idols ${ }^{54}$, and great throngs of demons ${ }^{55}$.

41 And each day these women ruin men, I and destroy each life with their sorcery ${ }^{56}$.

42 Escape their beauty, detect their faults! I Indeed, they are vessels of impurity ${ }^{57}$, disguised in precious and sacred garments ${ }^{58}$.

43 Abhor their looks, for indeed in the end I you will be pierced by sharp thorns and have skewers in your heart ${ }^{59}$.

44 Those who respond to these women are fools, I madmen are those who bow down to them and assent to them ${ }^{60}$.

45 And I will place as an example Melibea, to all her friends, I and Calisto, to all lovers and to all who desire ${ }^{61}$.

46 And they ${ }^{62}$ will turn from the peoples' path of desire ${ }^{63}$. I And they will be free from all the passion of its fire

54.- Cassuto refers here to Lev 17:7 ("And they shall no more sacrifice their sacrifices unto the satyrs, after whom they go astray. This shall be a statute for ever unto them throughout their generations »), but I can't see a direct parallel between the hemistich and the biblical verse.

55.- These reproaches seem to be the Jewish counterpart of «Por ellas es dicho: arma del diablo, cabeça de pecado, destruyción de paraýso» (p. 242),

56.- There is no reason to think this reference to «sorcery» could point to Celestina's magical arts, as it looks more like a metaphorical denomination for feminine charms.

57.- The Hebrew word for impurity [הדנ] used here by Tsarfati, has very strong connotations of immorality. For example, it may refer to idolatry (as in Ezra 9:11: "The land, unto which ye go to possess it, is an unclean land through the uncleanness of the peoples of the lands, through their abominations"), or the union of a man with his brother's wife (Lev 20:21: "And if a man shall take his brother's wife, it is impurity»). Furthermore, it has purely female connotations when relating to a woman's period of menstruation. In this way, Tsarfati's use of this word can be seen to completely feminise the nature of impurity on a metaphorical level, or it can be seen to refer literally to the woman's state of impurity when she is menstruating.

58.- This is quite similar to Sempronio's «iConsidera qué sesito está debaxo de aquellas grandes y delgadas tocas! ¡Qué pensamientos so aquellas gorgueras, so aquel fausto, so aquellas largas y autorizantes ropas! ¡Qué imperfición, qué alvañares debaxo de templos pintados!» (p. 242). The exclamation in the preceding hemistich seems to resume Sempronio's catalogue of feminine defects (pp. 241-242).

59.- I follow Carpenter's translation.

60.- Cassuto explains that מידומ is an allusion to the penultimate blessing of the ShemoneiEsrei prayer. Tsarfati's use of this word to imply the image of men assenting to women as the worshipper assents to God in prayer, is near-blasphemous and indicative of the ludicrous extent to which men worship the women with whom they fall in love. In a similar way, in Act I of Celestina, Calisto exclaims that in Melibea he sees the greatness of God.

61.- Rojas's highlights the exemplar value of Celestina too: «Vosotros que amáys, tomad este ensemplo» (p. 210, emphasis is mine).

62.- It is not easy to ascertain if the personal pronoun «they» refers to the objects of the previous verse, i.e. Melibea and her friends, and Calisto and all lovers; or to the male subject of verse 44 .

63.- Carpenter suggests the path of desire of the gentiles. Perhaps Tsarfati is trying to emphasise to his Jewish audience that the path of love is not within their social and religious ca- 
47 And from their hearts and from their innards. They will extinguish I its source and they will destroy it to its foundations.

48 Turn to me and incline your ears to my words ${ }^{64}$, I and rejoice with me, counsel and assembly of survivors ${ }^{65}$.

49 But is it wise for you to be shamed, my friends and aristocratic companions, I in devotion to bands of united maidens?

50 Or to be like a deer without power and without horns of strength ${ }^{66}$ ? Or like a goat, bound by the hand of women?

51 I am Joseph, son of rabbi Samuel, I prince to those united to the religion of those who have been established ${ }^{67}$;

52 A fountain of wisdom ${ }^{68}$ and a a spring of protection ${ }^{69}$, I the support of the stakes of Jacob's tent.

53 His name is Tsarfati. I Is it not he who has served great rulers and princes

54 Including Lord ${ }^{70}$ Julius, high priest of the nations ${ }^{71}$, I who has crushed the pride of the evil powers? ${ }^{72}$

pacity. However, Tsarfati had demonstrated great respect for non-Jewish nations throughout his life. He was, after all, physician to the Pope.

64.- Cassuto makes reference to Job 34:16: «hearken to the voice of my words». I consider an allusion to Prov 5:1 («My son, attend unto my wisdom; incline thine ear to my understanding») to be more significant. Not only does Tsarfati echo the use of the verb and the noun here, but also the content of Proverbs 5, which is a warning against the wiles of women.

65.- Tsarfati's reference to "survivors» may be to those survivors of the pursuit of love. However, this word may have greater connotations, extending to the history of the Jewish community, which has survived numerous persecutions and attempts at annihilation. Indeed, Tsarfati emphasises that his poem is intended solely for the Jewish community, and a reference to its continuity emphasises his empathy with his religious community. Furthermore, there could be an allusion to Esther 8.15 ("and the city of Shushan shouted and was glad») which epitomises this sense of survival, for it recounts a moment in which the Jews have survived annihilation and are celebrating victory over their enemy.

66.- Cassuto identifies an allusion to Ps 88:5: «I have become like a man who is helpless».

67.- Cassuto refers to Ps 148:6: «he has established them forever and ever and he has made a decree which shall not be transgressed".

68.- Prov 18:4: «The words of a man's mouth are as deep waters; a flowing brook, a fountain of wisdom».

69.- «Fountain» and «spring» appear together also in Hos 13:15 («and his spring shall become dry, and his fountain shall be dried up [...]»).

70.- Tsarfati's reference to Julius as וודא reveals his great reverence for the Pope. deed be used for "man", although its connotations regarding divine attributes are very strong.

71.- I have used Carpenter's literal translation.

72.- "who destroyed the pride of the vain» (Carpenter). Tsarfati may be referring to Julius's status as a "Warrior Pope» and his actions a year or so earlier in 1506, in which he managed to free Perugia and Bologna from the tyrannic oppression of their rulers. 
55 Truly my tongue has copied this work I to sweeten the suffering of the poor and the heart of pursued men $^{73}$.

56 And I do not translate word for word, I but I arrange the splendour of my discourse to my brethren: the Jews.

57 The crowd of scoffers arrayed against me I shall be judged measure for measure ${ }^{74}$,

58 And it is not in vain that Gehenna is burning within them. I There they will give an account of future deeds ${ }^{75}$.

59 Judge me on this score in my favour, I my people, pious ones adorned with comely ornaments.

60 May your brilliance quickly illuminate your minds I and may God grant you precious gifts!

61 When a graceful young maiden sets your heart alight I and you find yourself within a strong and calamitous fire

62 Hurry! Awaken! Turn as one! I Turn, friends, to the war of lovers ${ }^{76}$.

73.- In the acrostic stanzas Rojas develops this idea too: «atrae los oýdos de penadas gentes / de grado escarmientan y arrojan su carga» (p. 207).

74.- A Mishnaic phrase: מידודמ םתדמ. Found, for example, in Mishnah Sota 1:7. This idea of «measure for measure» can also be identified in Gen 9:6: "Whoever sheds the blood of man, by man shall his blood be shed».

75.- According to Cassuto, this appears in Mishnah Abot 3:1, 4:22: מידיתע ןידה.

76.- Tsarfati ends his poetic prologue with the same words and imagery with which he began in the first verse. This quality of ring composition is identifiable in medieval Hebrew poetry from Spain, in fact Pagis (1991: 25) explains that «the poem is supposed to conclude as it began, with a powerful image». In addition, Rojas's Tragicomedia repeats a similar structure if the octavas finales are taken into account, as they repeat the same concepts expressed in the acrostic stanzas that preceded the text. 


\section{Bibliography}

CARPenter, Dwayne E. (1993), "The sacred in the profane: Jewish Scriptures and the first comedy in Hebrew", in Fernando de Rojas and "Celestina»: approaching the fifth centenary, eds Ivy A. Corfis and Joseph T. Snow, Madison, Hispanic Seminary of Medieval Studies, pp. 229-237.

- (1997), "A Converso best-seller: Celestina and her foreign offspring», in Crisis and creativity in the Sephardic world, 1391-1648, ed. Benjamin R. Gampel, New York, Columbia University Press, pp. 267-281.

Cassuto, Moshe David (1935), "Me-Shirei Yosef ben Shmuel Zarfati: Ha-Komedia ha-Rishonah be-Ivrit [The poetry of Joseph ben Samuel Tsarfati: the first comedy in Hebrew]", in Jewish studies in memory of George A. Kohut 1874-1933, eds Salo Wittmayer Baron and Alexander Marx, New York, The Alexander Kohut Memorial Foundation, pp. 121-128.

McPheeters, Dean W. (1985), "Una traducción hebrea de La Celestina en el siglo XVI", in Estudios humanísticos sobre "La Celestina", Potomac MD, Scripta Humanistica, pp. 34-49.

Neubauer, Adolf and A.E. Cowley (1886), Catalogue of the Hebrew manuscripts in the Bodleian library, and in the college libraries of Oxford, Oxford.

PAGIS, Dan (1991), Hebrew poetry of the Middle Ages and the Renaissance, Berkeley, University of California Press.

Rojas, Fernando de (1991), Comedia o tragicomedia de Calisto y Melibea, ed. Peter E. Russell, Madrid, Castalia.

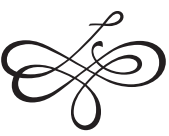


Baron, Amy, «English translation of A Poem Composed by the Poet upon his Translation of the Tale of Melibea and Calisto, Joseph ben Samuel Tsarfati, 1507», Celestinesca 36 (2012), pp. 35-46.

\section{RESUMEN}

Traducción al inglés del prólogo a la traducción hebrea de Celestina, realizada en el siglo XVI por Joseph ben Samuel Tsarfati.

Palabras Clave: Traducción de Celestina, Celestina en hebreo, Joseph ben Samuel Tsarfati.

\section{ABSTRACT}

Translation into English of the prologue to the $\mathrm{XVI}^{\text {th }}$ century Hebrew translation of Celestina by Joseph ben Samuel Tsarfati.

KEY WORDS: Celestina in translation, Celestina in Hebrew, Joseph ben Samuel Tsarfati.

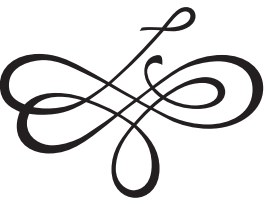

